\title{
Survey in Nurseries and Irrigation Water Reservoirs as Sources of Oomycetes Found in Avocado Orchards in the Canary Islands
}

\author{
Cristina Rodríguez-Padrón, ${ }^{1}$ Ana Rodríguez, ${ }^{2}$ and Felipe Siverio ${ }^{1,3, \dagger}$ \\ ${ }^{1}$ Departamento de Protección Vegetal, Instituto Canario de Investigaciones Agrarias, 38200 La Laguna, Tenerife, Canary Islands, \\ Spain; ${ }^{2}$ Departamento de Bioquímica, Microbiología, Biología Celular y Genética, Facultad de Farmacia, Universidad de La \\ Laguna, 38206 La Laguna, Tenerife, Canary Islands, Spain; and ${ }^{3}$ Sección de Laboratorio de Sanidad Vegetal, Consejería de Agri- \\ cultura, Ganadería, Pesca y Aguas del Gobierno de Canarias, 38270 La Laguna, Tenerife, Canary Islands, Spain
}

\begin{abstract}
Nursery stocks and irrigation water are important sources of Phytophthora spp. In this study, 20 irrigation water reservoirs and 10 avocado nurseries were surveyed in the Canary Islands between 2013 and 2015 to investigate their potential role in disseminating pathogenic species in avocado orchards. Phytophthora multivora was isolated from one of the irrigation reservoirs, whereas, in two surveys conducted in nurseries, Phytophthora cinnamomi, the primary pathogen in avocado, was detected in addition to other Phytophthora species (P. lacustris, P. multivora, P. nicotianae, $P$. niederhauserii, and P. palmivora) and Phytopythium vexans. The

species recovered from nurseries were isolated mostly from propagated plants but also from nursery irrigation water, soil used for substrate preparation, and soil samples collected in orchards that supply seeds for seedling propagation. Species recovered from nurseries correlated with those found in avocado orchards in a previous study, except for $P$. lacustris, suggesting that nurseries could be involved in their dissemination in avocado orchards. The improved sanitary status of nurseries resulted in reduced incidence in the second survey, indicating the importance of nursery monitoring to reduce infestations.
\end{abstract}

Avocado (Persea americana Mill.) is currently an important crop in the Canary Islands (Spain) that is grown on five of the seven main islands, with a cropped area of 1,393 ha and 9,427 t of annual production (Ministerio de Agricultura, Pesca y Alimentación, Spanish Government, https://www.mapama.gob.es/es/estadistica/ temas/estadisticas-agrarias/agricultura/superficies-produccionesanuales-cultivos/). Avocados are primarily grown in the Canary Islands in small orchards with approximately 1 ha or less, which are distributed from sea level to an altitude of $600 \mathrm{~m}$, although most are between 100 and $300 \mathrm{~m}$. These orchards are on cultivable plots with their corresponding native soils but also frequently in artificial plots (locally known as "sorribas") whose soils are brought from the most humid and fertile forest area located over $600 \mathrm{~m}$ above sea level. Plants for new avocado plantations in the Canaries are produced in local nurseries, because the introduction of avocado plants in the region is not allowed according to Order $\mathrm{N}^{\circ}$ 72: 8540-56 of the Spanish Government (BOE 1987). Most of these nurseries produce and/or commercialize other plant species in addition to avocado, and the rootstocks they use are mostly seedlings, because unlike other producing areas, clonal propagation of avocado rootstocks is not a common practice in the Canary Islands. Avocado nurseries are subjected to the Spanish Technical Regulation of Control and Certification of Fruit Nursery Plants (BOE 1995).

${ }^{\dagger}$ Corresponding author: F. Siverio; fsiverio@icia.es

Funding: This research was supported by project RTA2009-00157 from the Instituto Nacional de Investigación y Tecnología Agraria y Alimentaria (INIA, Spain). C. Rodríguez had a research grant from INIA and a work contract by the Servicio de Sanidad Vegetal del Gobierno de Canarias.

*The $\boldsymbol{e}$-Xtra logo stands for "electronic extra" and indicates that two supplementary tables are published online.

The author(s) declare no conflict of interest.

Accepted for publication 21 December 2018.

@ 2019 The American Phytopathological Society
Avocado root rot caused by Phytophthora cinnamomi, the major disease of this crop worldwide (Erwin and Ribeiro 1996; Pegg et al. 2002; Zentmyer 1980), was detected in the Canary Islands in 1975 (Gallo-Llobet et al. 1978) and has been reported on three of the five islands on which avocados are grown (Gallo et al. 1988; GalloLlobet et al 1985). Currently, $P$. cinnamomi remains a serious limitation to the avocado crop in the region despite the efforts performed for its control. In a recent study (Rodríguez-Padrón et al. 2018) in which we surveyed 99 avocado orchards in the Canary Islands for Phytophthora spp., P. cinnamomi was the species most frequently isolated. This pathogen was detected in a quarter of the surveyed orchards, but we also recovered other Phytophthora spp. identified as $P$. multivora, $P$. nicotianae, $P$. niederhauserii, and $P$. palmivora, in addition to isolates belonging to the Phytopythium vexans complex. $P$. multivora, $P$. niederhauserii, and $P p$. vexans were reported for the first time infecting avocado plants (RodríguezPadrón et al. 2018).

Environmental conditions and management practices in nurseries (warm temperature, high humidity, frequent transplants to pots, and close cultivation of many species and varieties) are favorable for growth and dissemination of Phytophthora species (Prigigallo et al. 2015). In fact, nursery stock infected with $P$. cinnamomi have been primarily responsible for the spread of avocado root rot, and as a consequence, sanitary measures adopted in avocado nurseries have traditionally focused on $P$. cinnamomi. However, other species should also be considered in avocado nurseries based on the results obtained in our previous work (RodríguezPadrón et al. 2018). Several alien invasive Phytophthora species such as $P$. ramorum and $P$. alni, which cause severe losses in forests of North America and Europe, have been emerging from nurseries over the last decade, triggering numerous surveys to investigate the occurrence of Phytophthora spp. in both ornamental and forest nurseries. As a result, an unexpected diversity of Phytophthora spp. has been detected (Bienapfl and Balci 2014; Ferguson and Jeffers 1999; Jung et al. 2016; Junker et al. 2016; Leonberger et al. 2013; Moralejo et al. 2009; Prigigallo et al. 2015; Prospero et al. 2013; Schwingle et al. 2007), and a similar situation could occur in avocado nurseries.

Natural waterways and irrigation water have the potential to harbor species of Phytophthora, Pythium, and Phytopythium (De Cock et al. 2015; Hüberli et al. 2013; Loyd et al. 2014; Zappia et al. 2014), 
although more comprehensive information is required to clarify their significance in spreading phytopathogenic species (Zappia et al. 2014). Water used for irrigation in the Canaries is primarily from groundwater and, to a lesser extent, from runoff or treated wastewater. The water is channeled and used directly for irrigation or stored in artificial reservoirs of public management. The forest area contributes significantly to the aquifer recharge on the most mountainous islands of the Canaries, in which the laurel forest (known as "laurisilva"), a valuable rainforest endemic of Macaronesia, collects water from the layer of mist that is formed at approximately $1,000 \mathrm{~m}$. Surveys in the laurel forest of the Canary Islands found P. multivora and several species of Pythium and Phytopythium, including $P p$. vexans (Beltrán et al. 2012). Additionally, a high diversity of Phytophthora species was subsequently detected by pyrosequencing in water and soil samples (Català et al. 2014). These findings are of concern because forest-inhabiting oomycetes could be introduced into avocado crops and nurseries through irrigation water and soil, particularly when we consider that most of the avocado nurseries in the Canaries use soil-containing substrates, and as previously indicated, forest soil is also used to condition agricultural land.

The objective of this study was to investigate the presence of Phytophthora and other oomycete species in irrigation water reservoirs and avocado nurseries from the Canary Islands and to determine whether those species detected in avocado orchards are found in these potential sources, particularly in the case of species previously unrecorded in avocado. In addition to nursery stock, substrates and irrigation water used in nurseries as well as soil samples collected from several orchards that supply them seeds intended for propagation were also analyzed.

\section{Materials and Methods}

Sampling and Phytophthora isolation in avocado nurseries. All registered nurseries that supply avocado plants in the Canaries were surveyed between April 2013 and February 2014 (survey 1) and between March and May 2015 (survey 2) for Phytophthora spp. and other oomycetes in propagated plants, irrigation water, and substrates. A total of 10 nurseries were surveyed (Table 1), with six nurseries in both surveys and the remaining four only in one survey, because those nurseries were not producing avocado plants when the survey was conducted. Most of these nurseries produced and/or commercialized other fruit trees or ornamental plants in addition to avocado, and their production was estimated at 72,000 and 57,500 avocado plants in survey 1 and survey 2 , respectively.

Avocado plants. Potted avocado plants were sampled from different producing batches (three plants per batch). The age of the plants ranged from 3 to 12 months, which were mostly seedlings obtained from local trees. Only one nursery produced clonal rootstocks in survey 1 . All the nurseries had their plants on benches separated from the ground by at least $30 \mathrm{~cm}$. Batches of plants were composed of ungrafted or grafted rootstocks with different varieties, depending on their stage of production (Table 1). Plant batches were visually inspected, and potted plants were collected among plants showing symptoms of root rot (e.g., foliar chlorosis, wilting, and defoliation) or randomly selected when no visible damage was observed in the batch. Each plant together with potting substrate was placed into a plastic bag that was immediately sealed and transported to laboratory.

Phytophthora spp. and other oomycetes were isolated directly from roots and from potting media of plants. Roots were cut into approximately 1 - to 2 -cm-long segments, washed under running tap water, surface disinfected by dipping in $70 \%$ ethanol for $30 \mathrm{~s}$, rinsed in sterile distilled water three times, blotted dry on filter paper, and plated onto Phytophthora selective $\mathrm{P}_{10} \mathrm{ARPH}$ medium (Jeffers and Martin 1986) and potato dextrose agar (PDA; Oxoid). Potting media of plants collected from the same batch were mixed and analyzed as a single sample and tested for Phytophthora by baiting, as previously described (Erwin and Ribeiro 1996; Scott et al. 2009) with minor modifications. Two hundred and fifty grams of potting medium was placed in a small plastic container $(8.5 \mathrm{~cm}$ high $\times 18 \mathrm{~cm}$ diameter) and moistened. Twenty-four hours later, $500 \mathrm{ml}$ of distilled water was added, and young leaves of $P$. americana 'Topa Topa' were used as baits. Small brownish lesions appearing in the leaves after 2 to 4 days were cut and plated onto $\mathrm{P}_{10} \mathrm{ARPH}$ and PDA media. The Petri dishes were incubated at $25^{\circ} \mathrm{C}$ in the dark and examined for growth over a 7-day period.

Substrates. The surveyed nurseries used different types of substrates as potting media: some nurseries used only peat or peat in combination with other products such as lapilli, coconut fiber, or perlite, whereas many others included soil in the potting medium (Table 1). In the former case, peat or substrate mix was sampled to test the presence of Phytophthora spp. and other oomycetes. In the

Table 1. Nurseries producing avocado plants in the Canary Islands surveyed in this study, with indication of the number of plant batches, production stage at the time of sampling, type of substrate, and rootstock used in propagation

\begin{tabular}{|c|c|c|c|c|c|c|c|c|}
\hline \multirow[b]{2}{*}{ Nursery } & \multicolumn{4}{|c|}{ Survey 1} & \multicolumn{4}{|c|}{ Survey 2} \\
\hline & Batches & Production stage $^{a}$ & Rootstocks $^{b}$ & Substrate & Batches & Production stage $^{a}$ & Rootstocks $^{b}$ & Substrate \\
\hline N1 & 3 & $\begin{array}{l}\text { Ungrafted } \\
\text { Grafted (Hass) }\end{array}$ & SL (WI, O) & Soil-containing & $\mathrm{NA}^{\mathrm{c}}$ & & & \\
\hline $\mathrm{N} 2$ & 3 & $\begin{array}{l}\text { Ungrafted } \\
\text { Grafted (Hass) }\end{array}$ & SL (WI, O) & Soil-containing & 5 & $\begin{array}{l}\text { Ungrafted } \\
\text { Grafted (Hass) }\end{array}$ & SL (WI, O) & Soil-containing \\
\hline $\mathrm{N} 3^{\mathrm{d}}$ & 2 & Ungrafted & SL (WI, O) & Soil-containing & 3 & $\begin{array}{l}\text { Ungrafted } \\
\text { Grafted (Hass, Fuerte) }\end{array}$ & SL (WI) & Peat \\
\hline $\mathrm{N} 4^{\mathrm{d}}$ & 3 & Ungrafted & SL (WI, O) & Peat & 2 & $\begin{array}{l}\text { Ungrafted } \\
\text { Grafted (Hass) }\end{array}$ & SL (WI, O) & Peat \\
\hline N5 & 2 & Ungrafted & SL (WI, O) & Soil-containing & $\mathrm{NA}^{\mathrm{c}}$ & & & \\
\hline N6 & 3 & $\begin{array}{l}\text { Ungrafted } \\
\text { Grafted (Hass, Fuerte) }\end{array}$ & Clonal (Duke 7) & Soil-containing & $\mathrm{NA}^{\mathrm{c}}$ & & & \\
\hline N7 & 3 & Grafted (Hass, Fuerte) & SL (WI) & Soil-containing & 6 & $\begin{array}{l}\text { Ungrafted } \\
\text { Grafted (Hass) }\end{array}$ & SL (WI, O) & Soil-containing \\
\hline N8 & 2 & $\begin{array}{l}\text { Ungrafted } \\
\text { Grafted (Fuerte) }\end{array}$ & SL (WI) & Soil-containing & 3 & Ungrafted & SL (WI) & $\begin{array}{l}\text { Peat-lapilli- } \\
\text { coconut fiber }\end{array}$ \\
\hline N9 & 9 & $\begin{array}{l}\text { Ungrafted } \\
\text { Grafted (Hass, Fuerte, } \\
\text { Pinkerton, Reed) }\end{array}$ & SL (WI) & Soil-containing & 5 & Ungrafted & SL (WI) & $\begin{array}{l}\text { Peat-perlite- } \\
\text { coconut fiber }\end{array}$ \\
\hline N10 & $\mathrm{NA}^{\mathrm{c}}$ & & & & 4 & Ungrafted & SL (WI) & Peat-lapilli \\
\hline
\end{tabular}


nurseries that used soil-containing substrates, the samples for analysis were from the bulk soil used to prepare the potting medium. Samples (approximately $1 \mathrm{~kg}$ ) were maintained at room temperature in plastic bags until processing as described above for potting media of propagated plants.

Irrigation water. Water samples were collected in the surveyed nurseries directly from the irrigation system or from storage tanks. Approximately 10 liters of water was taken from each nursery and passed through sterile Millipore filters of $5 \mu \mathrm{m}$ pore size (approximately 3 liters per filter) by pumping with an electric sprayer (MATABI Elegance 18 Plus, Goizper Group, Gipuzkoa, Spain). After filtration, the filters were placed inside a cut made in 'Granny Smith' apples previously surface disinfected with $70 \%$ ethanol. The cuts were sealed with Scotch tape, and the apples were incubated at room temperature until the appearance of lesions (4 to 7 days). The filters were removed when lesions appeared in the apple surfaces, and small brownish fragments of the advancing front of the lesion were plated onto $\mathrm{P}_{10} \mathrm{ARPH}$ and PDA media and incubated at $25^{\circ} \mathrm{C}$ in the dark for Phytophthora isolation.

Avocado orchards supplying seed to nurseries. Soil samples were collected as previously described (Rodríguez-Padrón et al. 2018) from eight avocado orchards from which seeds were collected to be used in the production of avocado plants in nurseries. Briefly, soil was taken at a depth of 10 to $20 \mathrm{~cm}$ from three points beneath individual trees and mixed into one sample of approximately $1 \mathrm{~kg}$. The samples were passed through a 5-mm mesh sieve and lateral roots separated from the soil. These soil samples were tested for Phytophthora by baiting, and the roots were disinfected and plated as previously described in this study for potting media of plants.

Sampling and Phytophthora isolation in irrigation water reservoirs. Water samples were collected from all but one of the agricultural irrigation water reservoirs located in Tenerife during the period of April to May 2013. The surveyed reservoirs belong to the island irrigation network, which is managed by the council of Tenerife. These reservoirs are constructed with foundations prepared with loose materials waterproofed with geomembrane, have a storage capacity of 14,000 to $821,739 \mathrm{~m}^{3}$, and are located between 110 and $1,317 \mathrm{~m}$ above sea level. Twenty reservoirs were sampled, with 17 of natural freshwater and three of treated wastewater. Samples (10 liters per reservoir) were collected from one spot and processed as previously described in this study for irrigation water from nurseries.

Morphological identification. After isolation, colonies suspected to be Phytophthora were transferred to PDA, corn meal agar (CMA, Oxoid), and clarified V8 juice agar (Erwin and Ribeiro 1996). Their initial identification was based on morphological features of colonies and hyphae, in addition to production and morphology of sporangia, oogonia, antheridia, oospores, and chlamydospores, according to the observations of Waterhouse et al. (1983), Gerrettson-Cornell (1994), Erwin and Ribeiro (1996), Gallegly and Hong (2008), Martin et al. (2012), and Abad et al. (2014). The formation of sporangia was induced by flooding plugs cut from actively growing V8 agar cultures with sterile and nonsterile soil extract (Erwin and Ribeiro 1996). Flooding plates were placed at room temperature under daylight and examined for sporangial development over a 7-day period. Sporangial production on sterile and/or nonsterile soil extract and sporangial characteristics such as shape and presence or absence of papilla were assessed by direct observation using an optical microscope (Nikon Eclipse 80i). The formation of oogonia, antheridia, and oospores was examined after 7 to 15 days of growth on V8 agar at $25^{\circ} \mathrm{C}$ in the dark. For heterothallic species, the isolates were paired with tester strains of $P$. cinnamomi (A1, BBA 69094; A2, 62660) and P. cryptogea (A1, BBA65909; A2, BBA63651) on V8 agar to stimulate the production of sexual structures. Plates were incubated for 2 to 3 weeks at $25^{\circ} \mathrm{C}$ in the dark and inspected for oogonial formation and antheridial attachment using an optical microscope.

For long-term storage, stock cultures were preserved on PDA and CMA slants covered with paraffin oil and in sterile soil extracts, as part of the collection maintained at the Instituto Canario de Investigaciones Agrarias (Canary Islands, Spain).
Molecular identification. $P$. cinnamomi isolates were confirmed by $P$. cinnamomi-specific polymerase chain reaction (PCR) using the primer pairs LPV2 and LPV3 as described by Kong et al. (2003) or by real-time PCR using SYBR Green as described by Nagle et al. (2010) but using the primer pairs LPV2. The identification of other isolated species was completed with the amplification of the region spanning the internal transcribed spacer (ITS) ITS1-5.8S-ITS2 of ribosomal DNA using the primers ITS-4 (5'-TCCTCCGCTTATT GATATGC-3') (White et al. 1990) and ITS-6 (5'-GAAGGT GAAGTCGTAACAAGG-3') (Cooke et al. 2000). Additionally, the ITS region of representative isolates of $P$. cinnamomi obtained in this study was also sequenced. Isolates were grown on PDA at $25^{\circ} \mathrm{C}$ in the dark for 1 to 2 weeks, and DNA extraction and ITS amplification were conducted as described by Pérez-Sierra et al. (2010). PCR products were purified and sequenced in both directions by the Genomic Service of the Universidad de La Laguna (La Laguna, Spain). MEGA6 software (Tamura et al. 2013) was used to assemble the forward and reverse sequences into consensus fragments. To provide consistency and quality of the sequences, the chromatograms of the sequences were checked, and primer sequences were trimmed off at both ends of the sequences. The sequences were subjected to an NCBI BLAST search (https://blast.ncbi.nlm.nih.gov/Blast.cgi) before phylogenetic analyses to identify the closest related sequences. Only published sequences were considered.

Phylogenetic analyses. Phylogenetic analyses were conducted separately for Phytophthora and Phytopythium species using neighbor-joining (Saitou and Nei 1987) and maximum likelihood methods as implemented in MEGA6 (Tamura et al. 2013). ITS sequences representing species from Phytophthora clades 1, 2, 4, 6, and 7 and species from the genus Phytopythium were downloaded from GenBank and combined with sequences derived during this study, including one representative isolate of each species isolated in each of the surveyed nurseries. All sequences used for phylogenetic analysis are shown in Tables 2 and 3.

Sequence data were initially aligned using the Clustal W program (Thompson et al. 1994), and manual adjustment was performed after visual examination by inserting gaps where necessary. In the neighbor-joining method, evolutionary distances were calculated using the Kimura two-parameter method (Kimura 1980). Maximum likelihood analysis of Phytophthora sequences was based on the Hasegawa-Kishino-Yano model (Hasegawa et al. 1985) with a discrete gamma distribution $(\mathrm{HKY}+\mathrm{G})$, which best described the observed substitution pattern among the combinations available. For Phytopythium sequences, the Kimura two-parameter model (Kimura 1980) with a discrete gamma distribution $(\mathrm{K} 2+\mathrm{G})$ was used for maximum likelihood analysis, because it provided the best-fit model using MEGA6. Node support was evaluated through 1,000 bootstrap pseudoreplicates.

Pathogenicity test of $\boldsymbol{P}$. lacustris. Pathogenicity of all species recorded in this work was previously evaluated with inoculation of avocado plants (Rodríguez-Padrón et al. 2018), except for P. lacustris, which was tested in this study in the same way. Briefly, 2-year-old avocado plants in 4-liter plastic pots (three plants for each isolate) were inoculated with $P$. lacustris (isolate $\mathrm{C} 078$ ) and $P$. cinnamomi as the positive control (isolate PcH15, ITS GenBank accession LM650983). Inocula were prepared by growing each isolate on PDA, and then the agar with mycelium was cut and buried in the pots around the roots (one Petri dish per pot), using uninoculated PDA plates for control plants. The plants were kept in a controlledtemperature greenhouse $\left(25 \pm 5^{\circ} \mathrm{C}\right)$ for 8 months and were flooded for $24 \mathrm{~h}$ every week. At the end of the experiment, plants were carefully removed from the pots, and the roots were gently washed with tap water. Root damage was assessed for each plant, both for severity of necrosis using a necrosis index from 0 to $3(0=$ no obvious symptoms; $1=$ less than $30 \%$ of the root system necrotic; $2=30$ to $70 \%$ of the root system necrotic; and $3=$ more than $70 \%$ of the root system necrotic) and by calculating the percentage (by dry weight) of lateral roots relative to the entire root system. Data were subjected to analysis of variance using Statistix 9 (Analytical Software), and means were separated by Fisher's least significant difference test at $P<0.05$. 


\section{Results}

Isolate identification and phylogenetic analyses. Phytophthora isolates obtained from nurseries and irrigation water reservoirs were identified as $P$. cinnamomi, $P$. lacustris, $P$. multivora, $P$. nicotianae, $P$. niederhauserii, and $P$. palmivora. Morphological identification of $P$. cinnamomi isolates was confirmed by conventional or real-time PCR using $P$. cinnamomi-specific primers and by ITS sequence analysis. $P$. nicotianae, $P$. niederhauserii, and $P$. palmivora isolates were also identified according to their morphological characteristics and confirmed by analyzing sequences of the ITS regions. Additionally, a set of Phytophthora isolates were identified as $P$. multivora based on ITS sequences. These isolates were morphologically identified as part of the P. citricola complex to which $P$. multivora belongs, but their morphological identification at the species level was not possible because of overlaps and similarities between the species described within this complex with regard to most characters (Scott et al. 2009). Furthermore, one sexually sterile Phytophthora isolate was obtained from the irrigation water of one of the nurseries. This isolate (C078) did not form gametangia or chlamydospores and produced noncaducous, nonpapillate, ovoid to obpyriform sporangia when colony plugs were submerged in nonsterile soil extract. These features are consistent with Phytophthora clade 6 taxa that have been isolated from aquatic habitats or riparian ecosystems (Brasier et al. 2003). Isolate C078 was identified as $P$. lacustris based on ITS homology (738 to 742 bp; $99.5 \%$ similarity) with the type isolate of $P$. lacustris. Figure 1 displays the phylogenetic analysis of representative isolates from each Phytophthora species obtained in this study and reference isolates (accession numbers are shown in Table 2). The ITS phylogeny grouped the isolates that were obtained from Canarian nurseries and irrigation water reservoirs with reference isolates of the species (90 to 100\% bootstrap support) within Phytophthora clade 1 (P. nicotianae), clade 2 (P. multivora), clade 4 (P. palmivora), clade 6 ( $P$. lacustris), and clade 7 ( $P$. cinnamomi and $P$. niederhauserii).

In this study, we also obtained a large group of isolates whose growth pattern and hyphae in young colonies resembled those of the genus Phytophthora. Sporangia and oogonia of these isolates showed similarities with those of Phytophthora genus, but the discharge of zoospores was similar to that of the genus Pythium. These characteristics fit with the genus Phytopythium described by Bala et al. (2010), to which the Pythium species belonging to clade $\mathrm{K}$ were formally transferred (De Cock et al. 2015). The ITS sequences of all isolates morphologically identified as a Phytopythium sp. showed high homology with published sequences of $P p$. vexans. Phylogenetic analysis of a set of seven representative $P p$. vexans

Table 2. Sequences of Phytophthora spp. used for phylogenetic analysis

\begin{tabular}{|c|c|c|c|c|c|}
\hline \multirow[b]{2}{*}{ Species } & \multicolumn{2}{|l|}{ Isolate code } & \multirow[b]{2}{*}{ GenBank accession ITS } & \multirow[b]{2}{*}{ Reference } & \multirow[b]{2}{*}{ ITS clade ${ }^{c}$} \\
\hline & International $^{\mathbf{a}}$ & Local $^{b}$ & & & \\
\hline Phytophthora alni & & P10564 & HQ261497 & Robideau et al. (2011) & 7 \\
\hline P. asparagi & VHS 17175 & & EU301167 & Burgess et al. (2009) & 6 \\
\hline P. cactorum & IMI 296524 & CAC2 & AF266772 & Cooke et al. (2000) & 1 \\
\hline P. capsici & CBS $12823^{\mathrm{d}}$ & & HQ643180 & Robideau et al. (2011) & 2 \\
\hline P. cambivora & IMI 296831 & CAM1 & AF266763 & Cooke et al. (2000) & 7 \\
\hline \multirow[t]{4}{*}{ P. cinnamomi } & & $\mathrm{C} 084$ & LN846113 & This study & 7 \\
\hline & & $\mathrm{C} 108$ & LN846114 & This study & 7 \\
\hline & & $\mathrm{C} 113$ & LN846129 & This study & 7 \\
\hline & CBS $14422^{\mathrm{d}}$ & & HQ643189 & Robideau et al. (2011) & 7 \\
\hline P. citricola & CBS $221.88^{\mathrm{d}}$, IMI $021173^{\mathrm{d}}$ & & FJ237526 & Scott et al. (2009) & 2 \\
\hline P. humicola & CBS $200.81^{\mathrm{d}}$ & & HQ643243 & Robideau et al. (2011) & 6 \\
\hline P. infestans & IMI 66006 & UQ2808 & AF266779 & Cooke et al. (2000) & 1 \\
\hline \multirow[t]{2}{*}{ P. lacustris } & & $\mathrm{C} 078$ & LN846125 & This study & 6 \\
\hline & IMI $389725^{\mathrm{d}}$ & $\mathrm{P} 245$ & AF266793 & Nechwatal et al. (2013) & 6 \\
\hline P. litoralis & CBS $127953^{d}$ & & HQ012948 & Jung et al. (2011) & 6 \\
\hline P. megakarya & IMI 337104 & UQ2822 & AF266782 & Cooke et al. (2000) & 4 \\
\hline P. megasperma & CBS $402.72^{d}$ & & HQ643275 & Robideau et al. (2011) & 6 \\
\hline P. melonis & CBS $582.69^{d}$ & & HQ643283 & Robideau et al. (2011) & 7 \\
\hline P. mengei & MYA-4554 & $42 \mathrm{~B} 2$ & EU748545 & Hong et al. (2009) & 2 \\
\hline P. multivesiculata & CBS $545.96^{d}$ & & HQ643288 & Robideau et al. (2011) & 2 \\
\hline \multirow[t]{4}{*}{ P. multivora } & & $\mathrm{C} 067$ & LN846124 & This study & 2 \\
\hline & & $\mathrm{C} 068$ & LN846115 & This study & 2 \\
\hline & & $\mathrm{C} 073$ & LN846116 & This study & 2 \\
\hline & CBS $124094^{\mathrm{d}}$, WAC $13201^{\mathrm{d}}$ & & FJ237521 & Scott et al. (2009) & 2 \\
\hline \multirow[t]{2}{*}{ P. nicotianae } & & C114 & LN846119 & This study & 1 \\
\hline & & UQ848 & AF266776 & Cooke et al. (2000) & 1 \\
\hline \multirow[t]{3}{*}{ P. niederhauserii } & & C101 & LN846117 & This study & 7 \\
\hline & & $\mathrm{C} 115$ & LN846118 & This study & 7 \\
\hline & WPC P10616 & & AY550915 & Abad et al. (2014) & 7 \\
\hline \multirow[t]{2}{*}{ P. palmivora } & & $\mathrm{C} 098$ & LN846126 & This study & 4 \\
\hline & & UQ1294 & AF266780 & Cooke et al. (2000) & 4 \\
\hline P. parvispora & CBS $132772^{d}$ & PH072 & KC478667 & Scanu et al. (2014) & 7 \\
\hline$P$. plurivora & CBS $124093^{d}$ & PLU-A5 & FJ665225 & Jung and Burgess (2009) & 2 \\
\hline P. tropicalis & CBS $434.91^{\mathrm{d}}$ & & HQ643369 & Robideau et al. (2011) & 2 \\
\hline
\end{tabular}

${ }^{\text {a }}$ CBS = Centraalbureau voor Schimmelcultures, Utrecht, Netherlands; IMI = CABI Bioscience (International Mycological Institute), United Kingdom; MYA = American Type Culture Collection (ATCC), Virginia, U.S.A.; VHS = Vegetation Health Service of the Department of Environment and Conservation, Perth, Australia; WAC = Department of Agriculture and Food Western Australia Plant Pathogen Collection, Perth, Australia; and WPC = World Phytophthora Collection, U.S.A.

${ }^{\mathrm{b}}$ Isolate names given in local culture collections.

c Internal transcribed spacer (ITS) clades according to Cooke et al. (2000).

$\mathrm{d}$ Type isolate. 
isolates recovered in this study grouped them with reference isolates belonging to the $P p$. vexans complex (accession numbers are shown in Table 3) into a single high-supported clade ( $99 \%$ bootstrap support), clearly distinct from other Phytopythium species (Fig. 2).

Recovery of Phytophthora spp. and Pp. vexans from avocado nurseries. The results of the surveys conducted in this study are summarized in Table 4 . More detailed information is provided in Supplementary Table S1 for survey 1 and Supplementary Table S2 for survey 2. Six Phytophthora species were isolated from seven of the nine nurseries investigated in survey 1 (Table 4). The species identified were the following: $P$. cinnamomi (three nurseries), $P$. lacustris (one nursery), $P$. multivora (two nurseries), $P$. nicotianae (one nursery), $P$. niederhauserii (two nurseries), and $P$. palmivora (one nursery). $P$. lacustris and $P$. palmivora were exclusively recovered from irrigation water, each species from a single nursery, whereas the other Phytophthora species were isolated from propagated plants and, in the case of $P$. cinnamomi and $P$. multivora, also from the soils used to prepare the potting mix in nurseries N9 and N3, respectively. Nursery N6 was highly infested with $P$. cinnamomi, because this pathogen was isolated from all the plant batches of the nursery. It is worth mentioning that three species pathogenic to avocado ( $P$. cinnamomi, $P$. nicotianae, and $P$. niederhauserii) were isolated from nursery $\mathrm{N} 9$, each one from a different plant batch, and $P$. niederhauserii was isolated from two of the three plant batches sampled in nursery N8. In addition to Phytophthora spp., Pp. vexans isolates were obtained from potted plants and/or soil used for substrate preparation in seven nurseries.
In survey 2, only two Phytophthora species were isolated from propagated plants: P. multivora from nursery $\mathrm{N} 3$ and $P$. nicotianae from nursery N2. As in survey 1 , the species most frequently isolated was $P p$. vexans, which was found in four of the seven nurseries surveyed (Table 4).

Soil samples collected from eight avocado orchards that supply seeds for use as seedling rootstocks by nurseries were tested for Phytophthora and other oomycetes. P. cinnamomi and Pp. vexans were isolated from one of the orchards; $P$. multivora, $P$. niederhauserii, and $P$ p. vexans from another one; and $P$ p. vexans from a third. No oomycete was detected from the other five avocado orchards.

Phytophthora recovery from irrigation water reservoirs. All but one of the agricultural water reservoirs for irrigation located on Tenerife were tested in this study. $P$. multivora (isolate C067) was the only species isolated from one of the 20 reservoirs surveyed, which collects fresh water and was located in northwestern Tenerife at $174 \mathrm{~m}$ above sea level.

Pathogenicity of $\boldsymbol{P}$. lacustris. The results of the pathogenicity test showed that $P$. lacustris did not cause root damage to avocado. At the end of the experiment, plants inoculated with $P$. lacustris did not show significant root necrosis (mean necrosis index of $0.3 \pm 0.3$ ) compared with that of controls in which no obvious symptoms of necrosis were observed in any plant. Additionally, no significant difference was found between $P$. lacustris-inoculated plants and controls for percentage of lateral roots with respect to the total root weight (mean values of $55.1 \pm 10.1$ and $47.5 \pm 2.4$, respectively). By contrast, $P$. cinnamomi caused severe root necrosis (more than $70 \%$ of

Table 3. Sequences of Phytopythium spp. used for phylogenetic analysis

\begin{tabular}{|c|c|c|c|c|}
\hline \multirow[b]{2}{*}{ Species } & \multicolumn{2}{|c|}{ Isolate code } & \multirow[b]{2}{*}{ GenBank accession ITS ${ }^{c}$} & \multirow[b]{2}{*}{ Reference } \\
\hline & International $^{\mathbf{a}}$ & Local $^{b}$ & & \\
\hline Pythium vexans $^{\mathrm{d}}$ & & UQ2074 & AF271224 & Cooke et al. (2000) \\
\hline Py. vexans ${ }^{\mathrm{d}}$ & & PPRI9086 & FJ415977 & McLeod et al. (2009) \\
\hline Py. vexans $\mathrm{d}$ & & Lev2210 & HQ643955 & Robideau et al. (2011) \\
\hline Py. vexans ${ }^{\mathrm{d}}$ & & STE-U6741 & GU133612 & Spies et al. (2011a) \\
\hline Py. vexans ${ }^{\mathrm{d}}$ & & STE-U6729 & GU133593 & Spies et al. (2011a) \\
\hline Py. vexans ${ }^{\mathrm{d}}$ & & STE-U6738 & GU133615 & Spies et al. (2011a) \\
\hline Py. vexans ${ }^{\mathrm{d}}$ & & STE-U6741 & GU133612 & Spies et al. (2011a) \\
\hline Py. vexans ${ }^{\mathrm{d}}$ & & STE-U6729 & GU133593 & Spies et al. (2011a) \\
\hline Py. vexans ${ }^{\mathrm{d}}$ & & STE-U6738 & GU133615 & Spies et al. (2011a) \\
\hline Py. vexans ${ }^{\mathrm{d}}$ & & IFAPA-CH837 & AM701798 & Unpublished \\
\hline Py. vexans ${ }^{\mathrm{d}}$ & MAFF 241117 & UZ215 & AB468784 & Uzuhashi et al. (2010) \\
\hline Py. amazonianum ${ }^{\mathrm{d}}$ & & P8247 & HQ261725 & Robideau et al. (2011) \\
\hline Py. cucurbitacearum ${ }^{\mathrm{d}}$ & $\begin{array}{l}\text { CBS } 748.96 \\
\text { IMI } 333340\end{array}$ & & AY598667 & Lévesque and De Cock (2004) \\
\hline Py. indigoferae ${ }^{\mathrm{d}}$ & CBS 261.30 & & AY598714 & Lévesque and De Cock (2004) \\
\hline Phytopythium aff. vexans ${ }^{\mathrm{d}}$ & CBS 26130 & & HQ643371 & Robideau et al. (2011) \\
\hline \multirow[t]{8}{*}{ Pp. vexans ${ }^{\mathrm{d}}$} & CBS 119.80 & BR 484 & AY598713 & Lévesque and De Cock (2004) \\
\hline & & $\mathrm{C} 069$ & LN846127 & This study \\
\hline & & $\mathrm{C} 071$ & LN846120 & This study \\
\hline & & $\mathrm{C} 074$ & LN846121 & This study \\
\hline & & $\mathrm{C} 079$ & LN846122 & This study \\
\hline & & $\mathrm{C} 087$ & LN846130 & This study \\
\hline & & C099 & LN846128 & This study \\
\hline & & $\mathrm{C} 110$ & LN846123 & This study \\
\hline Pp. boreale & CBS 551.88 & & AY598662 & Lévesque and De Cock (2004) \\
\hline Pp. chamaihyphon & CBS 259.30 & & AY598666 & Lévesque and De Cock (2004) \\
\hline Pp. helicoides & CBS 286.31 & & AY598665 & Lévesque and De Cock (2004) \\
\hline Pp. litorale & CBS 118360 & & HQ643386 & Robideau et al. (2011) \\
\hline Pp. ostracodes & CBS 768.73 & & HQ643395 & Robideau et al. (2011) \\
\hline Pp. sindhum & CBS 124520 & & HM244827 & Bala et al. (2010) \\
\hline
\end{tabular}

${ }^{a}$ CBS = Centraalbureau voor Schimmelcultures, Utrecht, Netherlands; IMI = CABI Bioscience (International Mycological Institute), United Kingdom; MAFF = and Microbiological Genebank, National Institute of Agrobiological Sciences, Tsukuba, Ibaraki, Japan.

${ }^{\mathrm{b}}$ Isolate names given in local culture collections.

${ }^{c}$ ITS = internal transcribed spacer.

${ }^{\mathrm{d}}$ Isolate included to the Pp. vexans complex. Py. vexans has been renamed Pp. vexans. 
the root system was necrotic in all inoculated plants) and significant loss of lateral roots (mean percentage of lateral roots of $23.9 \pm 4.2$ ).

\section{Discussion}

Nursery plants are important sources of invasive plant pathogens that can affect agricultural crops or native ecosystems. Phytophthora spp. are associated with nurseries worldwide, including highly virulent plant-pathogenic species and soil-associated or aquatic saprophytes and opportunists. Many studies were conducted in ornamental and forest nurseries over the last decade to determine their involvement in the spread of Phytophthora spp. (Bezuidenhout et al. 2010; Bienapfl and Balci 2014; Leonberger et al. 2013; Moralejo et al. 2009; Mrázková et al. 2013; Pérez-Sierra et al. 2012; Prospero et al. 2013). The importance of nurseries in the dissemination of

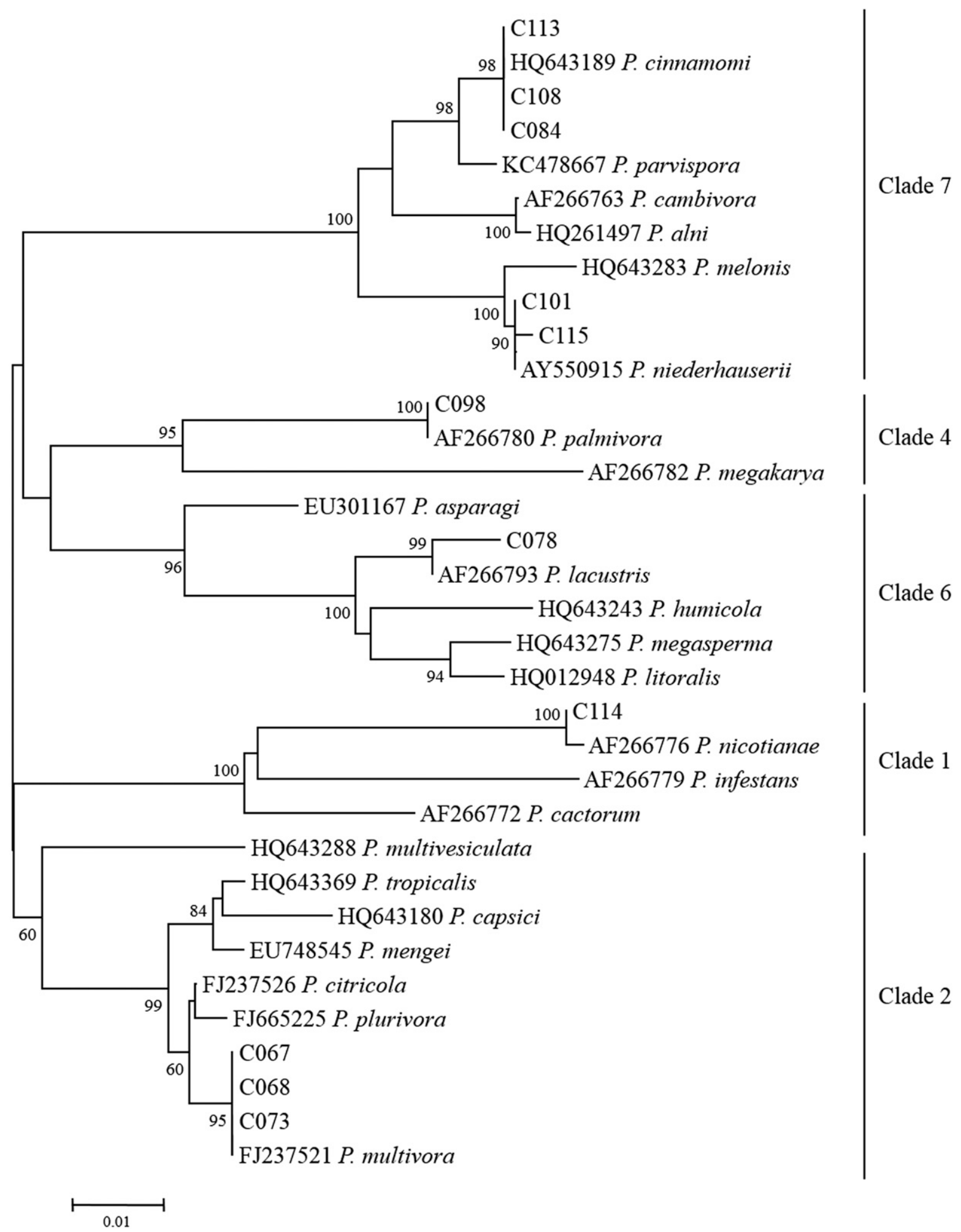

Fig. 1. Phylogenetic tree constructed by the neighbor-joining method based on rDNA-ITS sequences showing the position of Phytophthora isolates obtained in this study in the clades $1,2,4,6$, and 7 defined by Cooke et al. (2000). Numbers at the nodes of clusters represent bootstrap values generated from 1,000 pseudoreplicates (only values greater than or equal to $60 \%$ are shown). 
$P$. cinnamomi to avocado orchards is a well-known fact, and the control of this pathogen in nurseries is part of the integrated management of avocado root rot (Coffey 1987). However, available information about other Phytophthora spp. in avocado nurseries is notably lacking.

In the Canary Islands, no systematic surveys of avocado nurseries for $P$. cinnamomi were conducted in previous years, and the presence of other oomycetes has never been studied. In a recent work (Rodríguez-Padrón et al. 2018), P. cinnamomi was the most frequent species isolated from avocado orchards on the Canary Islands, but other Phytophthora spp. were also recovered, including $P$. multivora, $P$. nicotianae, $P$. niederhauserii, and $P$. palmivora. The species $P p$. vexans was also frequently isolated (Rodríguez-Padrón et al. 2018). In the present study, all the aforementioned species were isolated from nurseries, suggesting that they could be involved in their dispersal into commercial orchards. $P$. cinnamomi, $P$. multivora, $P$. nicotianae, $P$. niederhauserii, and $P p$. vexans were all isolated from potted plants, whereas $P$. palmivora was only isolated from irrigation water in a nursery during the first survey. The only species recovered from nurseries that was not found in avocado orchards was $P$. lacustris, which was isolated from irrigation water in one nursery. Phytophthora spp. recovered in this study have been previously reported from nurseries worldwide, including Europe (Jung et al. 2016; Moralejo et al. 2009; Pérez-Sierra et al. 2012), the United States (Leonberger et al. 2013; Schwingle et al. 2007), South Africa (Bezuidenhout et al. 2010), and Australia (Davison et al. 2006; Hardy and Sivasithamparam 1988), in addition to Pp. vexans (Lehtijärvi et al. 2017; Spies et al. 2011b).

Nurseries are complex systems characterized by a large heterogeneity of plant material and cultural methods. This complexity entails a difficulty for pathogen control, because each plant species is susceptible to infection by several pathogens, and symptoms caused by new pathogens may not be recognized. Additionally, infested pots and potting media are usually unnoticed, and infected plants may not show aboveground symptoms, particularly in the case of root pathogens at early stages of infection or as a result of pesticide treatments

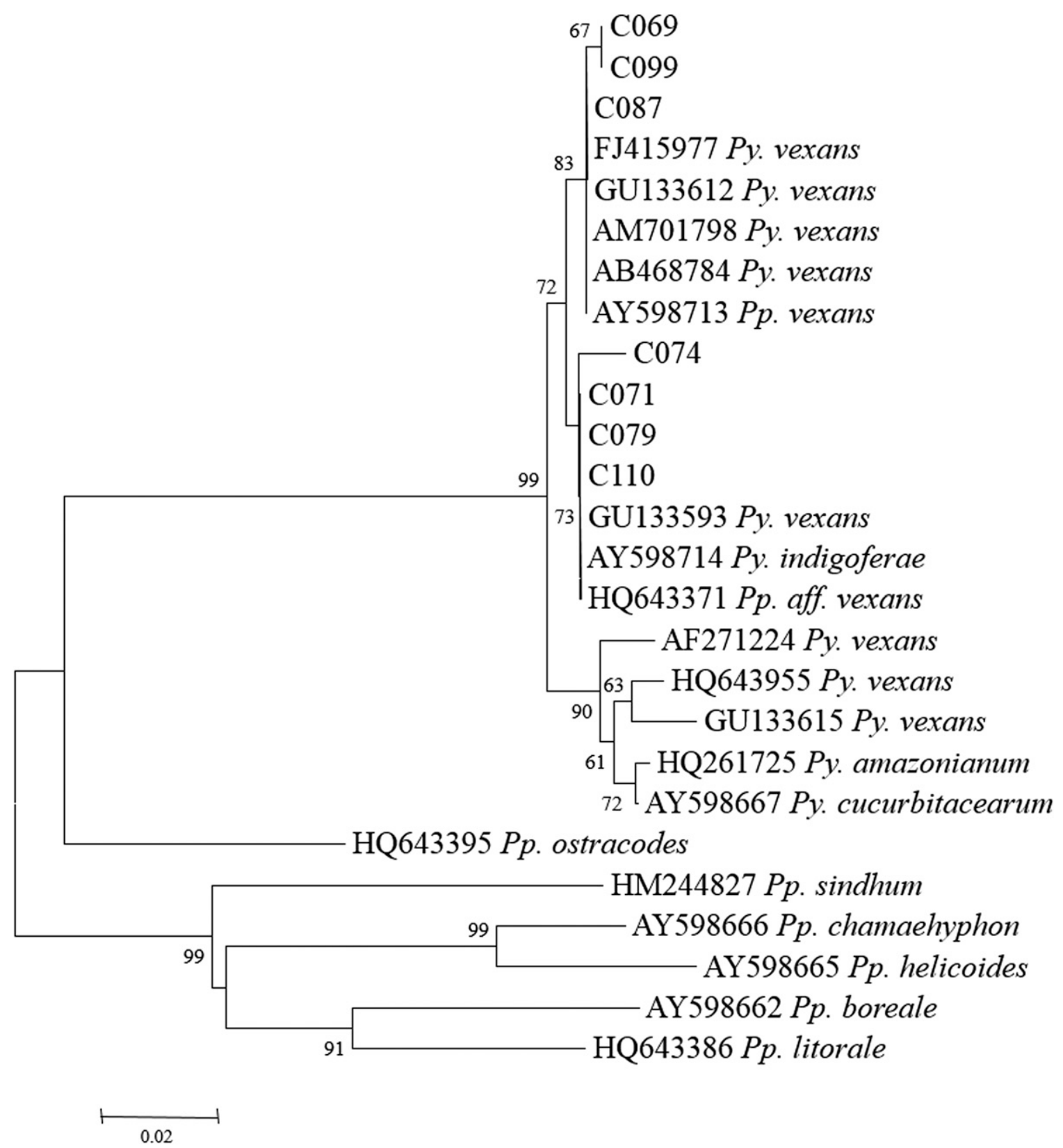

Fig. 2. Phylogenetic tree of Phytopythium spp. constructed by the neighbor-joining method based on rDNA-ITS sequences showing the position of Phytopythium isolates obtained in this study within the Phytopythium vexans complex. Numbers at the nodes of clusters represent bootstrap values generated from 1,000 pseudoreplicates (only values greater than $60 \%$ are shown). $P p .=$ Phytopythium; $P y .=$ Pythium; Py. vexans was renamed $P$. vexans. 
that hinder symptom development temporarily. Moreover, typical nursery production cycles involve propagated plants that are repotted and moved several times within the nursery, which facilitates pathogen dissemination (Bienapfl and Balci 2014; Parke and Grünwald 2012; Parke et al. 2014). Recently, Jung et al. (2016) compiled a list of Phytophthora spp. detected in 732 nurseries in 23 European countries over 40 years. Forty-nine Phytophthora taxa were recorded in 670 of these nurseries $(91.5 \%)$, demonstrating the ubiquitous Phytophthora infestations of nursery stocks, which represent a serious threat to forest and seminatural ecosystems.

The fact that $P$. cinnamomi was detected infecting plant batches in one-third of nurseries in the first survey indicated that nursery stocks have most likely been a pathway of disseminating $P$. cinnamomi to avocado orchards in the Canary Islands in recent years. One of these nurseries was highly infested, because $P$. cinnamomi was isolated from all plant batches, suggesting the pathogen had been in the nursery for a long time, multiplying repeatedly in propagated plants and contaminating the different materials involved in its production. Detection of plant batches infected with $P$. niederhauserii in two nurseries during the first survey is also of particular concern, because this species is a demonstrated aggressive pathogen to avocado plants (Rodríguez-Padrón et al. 2018). P. niederhauserii is currently considered an emerging pathogen in nurseries that has been isolated from more than 30 plant species and whose recent worldwide spread has been attributed to trade of ornamental and exotic plants (Abad et al. 2014). Therefore, the most likely hypothesis is that $P$. niederhauserii has been recently introduced in the Canary Islands through nursery plant trade, as in other regions. $P$. niederhauserii has been reported in forest and ornamental nurseries in different European regions (Jung et al. 2016), including mainland Spain, in which it was first isolated from diseased plants in ornamental nurseries (Moralejo et al. 2009) and later from young almond trees in field-grown nurseries (Pérez-Sierra et al. 2010), suggesting that ornamental plants may be responsible for the dissemination of this pathogen in nurseries dedicated to the production of fruit trees.

Among the other species isolated from plant batches, P. multivora and $P$ p. vexans varied in pathogenicity to avocado depending on isolate (Rodríguez-Padrón et al. 2018), whereas P. nicotianae is a well-known plant-pathogenic species that can attack many hosts, including avocado. The latter is one of the most common Phytophthora species found in ornamental nurseries on the Spanish mainland (Moralejo et al. 2009; Pérez-Sierra et al. 2012) and in other Mediterranean regions of Europe (Jung et al. 2016). In contrast, P. multivora and $P$. vexans have been detected in soil and water samples collected from native forests in the Canary Islands (Beltrán et al. 2012; Català et al. 2014), suggesting they could be native or were introduced long ago. The fact that $P$. multivora was also isolated in this study from one irrigation reservoir that collects water from natural sources supports this hypothesis. This finding is also consistent with the widespread occurrence of Pp. vexans in nurseries reported here and in avocado orchards previously described (Rodríguez-Padrón et al. 2018).

For Phytophthora spp., the primary way of introduction into new regions is with the international trade of exotic or ornamental plants (Brasier 2008), and a part of the entrances of invasive species in the Canary Islands most likely occurred in this way. Therefore, nurseries

Table 4. Positive isolation of Phytophthora species and Phytopythium (Pp.) vexans from irrigation water, substrate or soil used for substrate preparation, and potted plants in avocado nurseries of the Canary Islands. Number of positives of total plant batches tested is indicated in parentheses.

\begin{tabular}{|c|c|c|c|c|c|c|c|c|c|c|c|c|}
\hline \multirow[b]{2}{*}{ Nursery } & \multicolumn{8}{|c|}{ Survey 1} & \multicolumn{4}{|c|}{ Survey 2} \\
\hline & Sample & $\begin{array}{c}P . \\
\text { cinnamomi }\end{array}$ & $\begin{array}{c}P . \\
\text { lacustris }\end{array}$ & $\begin{array}{c}P . \\
\text { multivora }\end{array}$ & $\begin{array}{c}P . \\
\text { nicotianae }\end{array}$ & $\begin{array}{c}P . \\
\text { niederhauserii }\end{array}$ & $\begin{array}{c}P . \\
\text { palmivora }\end{array}$ & $\begin{array}{c}\text { Pp. } \\
\text { vexans }\end{array}$ & Sample & $\begin{array}{c}P . \\
\text { multivora }\end{array}$ & $\begin{array}{c}P . \\
\text { nicotianae }\end{array}$ & $\begin{array}{c}\text { Pp. } \\
\text { vexans }\end{array}$ \\
\hline \multirow[t]{3}{*}{ N1 } & Water & - & - & - & - & - & - & - & $\mathrm{NA}^{\mathrm{a}}$ & & & \\
\hline & Soil $^{\mathrm{b}}$ & - & - & - & - & - & - & - & & & & \\
\hline & Plants & - & - & - & - & - & - & $+(1 / 3)$ & & & & \\
\hline \multirow[t]{3}{*}{$\mathrm{N} 2$} & Water & - & - & - & - & - & - & - & Water & - & - & - \\
\hline & Soil $^{\mathrm{b}}$ & - & - & - & - & - & - & + & Soil $^{\mathrm{b}}$ & - & - & - \\
\hline & Plants & - & - & $+(2 / 3)$ & - & - & - & - & Plants & - & $+(1 / 5)$ & $+(2 / 5)$ \\
\hline \multirow[t]{3}{*}{$N 3^{c}$} & Water & - & - & - & - & - & - & - & Water & - & - & - \\
\hline & Soil $^{\mathrm{b}}$ & - & - & + & - & - & - & - & Substr. $^{\mathrm{d}}$ & $\mathrm{NT}^{\mathrm{e}}$ & & \\
\hline & Plants & - & - & $+(1 / 2)$ & - & - & - & $+(1 / 2)$ & Plants & $+(1 / 3)$ & - & $+(1 / 3)$ \\
\hline \multirow[t]{3}{*}{$\mathrm{N} 4^{\mathrm{c}}$} & Water & - & - & - & - & - & - & - & Water & - & - & - \\
\hline & Substr. $^{\mathrm{d}}$ & - & - & - & - & - & - & - & Substr. $^{\mathrm{d}}$ & - & - & - \\
\hline & Plants & - & - & - & - & - & - & - & Plants & - & - & - \\
\hline \multirow[t]{3}{*}{ N5 } & Water & - & + & - & - & - & - & - & $\mathrm{NA}^{\mathrm{a}}$ & & & \\
\hline & Soil $^{\mathrm{b}}$ & - & - & - & - & - & - & - & & & & \\
\hline & Plants & - & - & - & - & - & - & $+(2 / 2)$ & & & & \\
\hline \multirow[t]{3}{*}{ N6 } & Water & - & - & - & - & - & - & - & $\mathrm{NA}^{\mathrm{a}}$ & & & \\
\hline & Soil $^{\mathrm{b}}$ & - & - & - & - & - & - & - & & & & \\
\hline & Plants & $+(3 / 3)$ & - & - & - & - & - & $+(3 / 3)$ & & & & \\
\hline \multirow[t]{3}{*}{ N7 } & Water & - & - & - & - & - & + & - & Water & - & - & - \\
\hline & Soil ${ }^{\mathrm{b}}$ & - & - & - & - & - & - & + & Soil ${ }^{\mathrm{b}}$ & - & - & - \\
\hline & Plants & - & - & - & - & $+(2 / 3)$ & - & $+(1 / 3)$ & Plants & - & - & $+(2 / 6)$ \\
\hline \multirow[t]{3}{*}{ N8 } & Water & - & - & - & - & - & - & - & Water & - & - & - \\
\hline & Soil $^{\mathrm{b}}$ & - & - & - & - & - & - & - & Substr. $^{d}$ & - & - & + \\
\hline & Plants & $+(1 / 2)$ & - & - & - & - & - & $+(1 / 2)$ & Plants & - & - & $+(2 / 3)$ \\
\hline \multirow[t]{3}{*}{ N9 } & Water & - & - & - & - & - & - & - & Water & - & - & - \\
\hline & Soil $^{\mathrm{b}}$ & + & - & - & - & - & - & - & Substr. $^{\mathrm{d}}$ & - & - & - \\
\hline & Plants & $+(1 / 9)$ & - & - & $+(1 / 9)$ & $+(1 / 9)$ & - & - & Plants & - & - & - \\
\hline \multirow[t]{3}{*}{ N10 } & $\mathrm{NA}^{\mathrm{a}}$ & & & & & & & & Water & - & - & - \\
\hline & & & & & & & & & Substr. $^{d}$ & - & - & - \\
\hline & & & & & & & & & Plants & - & - & - \\
\hline
\end{tabular}


that share the production and commercialization of avocado plants with other foreign plant species are at a higher risk of contamination. Only two of the 10 nurseries surveyed in this work produced and commercialized solely avocado plants, with the others also producing other fruit trees such as mango or citrus, in addition to ornamental and exotic plants. Therefore, the Spanish Technical Regulation of Control and Certification of Fruit Nursery Plants (BOE 1995) requires that the area of production and commercialization of avocado plants be kept separate from other plant species when they are in the same nursery. This regulation also indicates that substrates must be disinfected before their use, because potting media can harbor pathogenic species, particularly when soil is used in their preparation. In this study, no oomycetes were isolated from soil-free substrates. Our results showed that some species isolated from potted plants were also found in the soil of these nurseries used for substrate preparation, indicating that soil could be acting as a source of plant-associated oomycete species. This was the case for $P p$. vexans, $P$. multivora, and $P$. cinnamomi and was of particular concern for P. cinnamomi.

Another measure included in regulations to prevent the introduction of $P$. cinnamomi in nurseries refers to the seeds used for plant propagation. This pathogen can infect avocado seed through fruit when it drops on the ground; therefore, the Spanish Technical Regulation (BOE 1995) recommends that seeds used in propagation should be picked from the tree and requires their treatment with hot water $\left(30 \mathrm{~min}\right.$ at 49 to $50^{\circ} \mathrm{C}$ ) (Coffey 1987 ; Zentmyer et al. 1958). The results obtained in this work indicated the importance of the application of this measure, because P. cinnamomi was detected in one of the orchards from which nurseries obtained seeds. Other oomycete species were also isolated from these orchards, including $P$. niederhauserii, $P$. multivora, and $P p$. vexans. Whether these species can infect avocado fruits and penetrate the seeds is unknown, but a risk occurs that these soil-borne oomycetes may be inadvertently moved to nurseries through wheels of agricultural machinery, tools, equipment, or worker's footwear.

Water can also be a pathway for disseminating plant pathogens; therefore, many species of Phytophthora, Pythium, and Phytopythium are isolated from natural waterways and irrigation systems (Català et al. 2014; Hüberli et al. 2013; Loyd et al. 2014; Martin et al. 2012; Nechwatal et al. 2013; Oh et al. 2013; Reeser et al. 2011; Stamler et al. 2016; Zappia et al. 2014). In this study, P. multivora was isolated from a reservoir intended for agricultural irrigation. Additionally, P. palmivora and P. lacustris were isolated from water used for irrigation in two nurseries. $P$. lacustris, which was found in nurseries but not in avocado orchards, has recently been described within clade 6 of Phytophthora (Nechwatal et al. 2013) and was formerly known as $P$. taxon Salixsoil. Similar to other species included in clade $6, P$. lacustris occurs naturally in aquatic environments and does not produce sexual structures in vitro, which has been suggested to be an adaptation to riparian conditions. The species is widespread in Europe and has also been detected in Australia, New Zealand, and the United States (Brasier et al. 2003; Jung et al. 2011; Nechwatal et al. 2013). Although P. lacustris is assumed to have a lifestyle that is prevalently saprophytic, this species may also act as an opportunistic pathogen in wet habitats. According to Nechwatal et al. (2013), the pathogenic potential to cultivated fruit trees requires further investigation, because the species apparently entered the nursery trade in Europe, causing root rots in commercial Prunus and other fruit tree plantations. According to our results of a pathogenicity test, $P$. lacustris did not cause significant damage to avocado plants.

In this study, potential sources of contamination were identified in Canarian avocado nurseries, including orchards from which seeds were obtained, soil used for substrate preparation, and irrigation water, which are all pathways by which pathogens may be introduced into nurseries. Moreover, infested plant batches may maintain and disperse Phytophthora spp. and other oomycetes within the nursery. Clearly, all steps of the production process may be contributing to the subsequent contamination of the plants, taking into account that with early contamination, the risk increases of having many infected plants at the end of production. Disease incidence in nurseries decreased after the implementation of prevention programs, and Sims et al. (2019) provided evidence that their application significantly reduced Phytophthora in plant nursery stock.

Although sanitary measures in avocado nurseries focus on the control of $P$. cinnamomi, the Spanish Technical Regulation on Control and Certification of Fruit Nursery Plants (BOE 1995) also refers explicitly to the control of Rosellinia necatrix, because this fungus is considered an important pathogen of avocado crops in mainland Spain. However, this pathogen does not cause significant losses in the Canary Islands and was not detected in any of the surveyed nurseries (data not shown).

Importantly, other species such as $P$. niederhauserii or $P$. nicotianae that could cause severe damage to avocado and that have been detected in nurseries should be considered in the control programs in addition to $P$. cinnamomi. During the first survey, simultaneous with nursery sampling, government technical staff responsible for plant health inspected the nurseries to check compliance with the Spanish standard regulations. As a result, the competent authority in the matter demanded the contaminated batches be destroyed, and that regulation was applied in cases of noncompliance. Consequently, the sanitary status of nurseries improved noticeably during the second survey, which is a good indicator of how nursery monitoring can help reduce infestations. Finally, but importantly, surveys and analyses of other plant species that also grow in nurseries of avocados have to be considered in future studies to understand the possible origins of the Phytophthora species detected.

\section{Acknowledgments}

The authors greatly appreciate the Servicio de Producción y Registros Agrícolas del Gobierno de Canarias and the Gestión del Medio Rural de Canarias, S.A.U. (GMR Canarias) for their collaboration in the collection of samples from nurseries, and thanks to Entidad Pública Empresarial BALTEN for technical support in the collection of samples from water reservoirs. The authors also thank the Sección de Laboratorio de Sanidad Vegetal del Gobierno de Canarias for use of facilities and laboratory equipment.

\section{Literature Cited}

Abad, Z. G., Abad, J. A., Cacciola, S. O., Pane, A., Faedda, R., Moralejo, E., PérezSierra, A., Abad-Campos, P., Álvarez-Bernaola, L. A., Bakonyi, J., Józsa, A., Herrero, M. L., Burgess, T. I., Cunnington, J. H., Smith, I. W., Balci, Y., Blomquist, C., Henricot, B., Denton, G., Spies, C., McLeod, A., Belbahri, L., Cooke, D., Kageyama, K., Uematsu, S., Kurbetli, I., and Değirmenci, K. 2014. Phytophthora niederhauserii sp. nov., a polyphagous species associated with ornamentals, fruit trees and native plants in 13 countries. Mycologia 106: 431-447.

Bala, K., Robideau, G. P., Lévesque, C. A., De Cock, A. W. A. M., Abad, G., Lodhi, M. A., Shahzad, S., Ghaffar, A., and Coffey, M. D. 2010 Phytopythium Abad, de Cock, Bala, Robideau, Lodhi \& Lévesque, gen. nov. and Phytopythium sindhum Lodhi, Shahzad \& Lévesque, sp. nov. Persoonia 24:136-137.

Beltrán, A., León, M., Abad-Campos, P., Siverio, F., Gallo, L., and Pérez-Sierra, A. 2012. Estudios preliminares sobre la presencia de oomicetos en la laurisilva en Tenerife. Page 347 in: XVI Congreso de la Sociedad Española de Fitopatología, Málaga, Spain.

Bezuidenhout, C. M., Denman, S., Kirk, S. A., Botha, W. J., Mostert, L., and McLeod, A. 2010. Phytophthora taxa associated with cultivated Agathosma, with emphasis on the $P$. citricola complex and $P$. capensis sp. nov. Persoonia 25:32-49.

Bienapfl, J. C., and Balci, Y. 2014. Movement of Phytophthora spp. in Maryland's nursery trade. Plant Dis. 98:134-144.

BOE. 1987. Ministerio de Agricultura, Pesca y Alimentación del Gobierno de España. Orden $\mathrm{N}^{\circ}$ 72: 8540-56 de 12 de marzo de 1987 por la que se establecen para las Islas Canarias las Normas Fitosanitarias relativas a la importación, exportación y tránsito de vegetales y productos vegetales. Boletín Oficial del Estado, Madrid, Spain.

BOE. 1995. Ministerio de Agricultura, Pesca y Alimentación del Gobierno de España. Real Decreto 929/1995, de 9 de junio por el que se aprueba el Reglamento técnico de control y certificación de plantas de vivero de frutales. Texto consolidado. Última modificación: 3 de noviembre de 2014 . (BOE $\left.{ }^{\circ} 141\right)$. Boletín Oficial del Estado, Madrid, Spain.

Brasier, C. M. 2008. The biosecurity threat to the UK and global environment from international trade in plants. Plant Pathol. 57:792-808.

Brasier, C. M., Cooke, D. E. L., Duncan, J. M., and Hansen, E. M. 2003. Multiple new phenotypic taxa from trees and riparian ecosystems in Phytophthora gonapodyides- $P$. megasperma ITS clade 6 , which tend to be hightemperature tolerant and either inbreeding or sterile. Mycol. Res. 107:277-290.

Burgess, T. I., Webster, J. L., Ciampini, J. A., White, D., Hardy, G. E. St. J., and Stukely, M. J. C. 2009. Re-evaluation of Phytophthora species isolated during 
30 years of vegetation health surveys in Western Australia using molecular techniques. Plant Dis. 93:215-223.

Català, S., Pérez-Sierra, A., Rodríguez Padrón, C., Siverio de la Rosa, F., and Abad-Campos, P. 2014. Discovering Phytophthora species in the laurel forest in Tenerife and La Gomera islands (Canary Islands, Spain). Page 78 in: 7th Meeting of IUFRO WP 7.02.09 Phytophthora in Forests \& Natural Ecosystems. Esquel, Argentina.

Coffey, M. D. 1987. Phytophthora root rot of avocado: An integrated approach to control in California. Plant Dis. 71:1046-1052.

Cooke, D. E. L., Drenth, A., Duncan, J. M., Wagels, G., and Brasier, C. M. 2000. A molecular phylogeny of Phytophthora and related oomycetes. Fungal Genet. Biol. 30:17-32.

Davison, E. M., Drenth, A., Kumar, S., Mack, S., Mackie, A. E., and McKirdy, S. 2006. Pathogens associated with nursery plants imported into Western Australia. Australas. Plant Pathol. 35:473-475.

De Cock, A. W. A. M., Lodhi, A. M., Rintoul, T. L., Bala, K., Robideau, G. P., Gloria Abad, Z., Coffey, M. D., Shahzad, S., and Lévesque, C. A. 2015. Phytopythium: Molecular phylogeny and systematics. Persoonia 34:25-39.

Erwin, D. C., and Ribeiro, O. K. 1996. Phytophthora Diseases Worldwide. American Phytopathological Society Press, St. Paul, MN.

Ferguson, A. J., and Jeffers, S. N. 1999. Detecting multiple species of Phytophthora in container mixes from ornamental crop nurseries. Plant Dis. 83:1129-1136.

Gallegly, M. E., and Hong, C. X. 2008. Phytophthora: Identifying species with morphology and DNA fingerprints. American Phytopathological Society Press, St. Paul, MN.

Gallo, L., Hernández, J., Jaizme, M. C., and Sala, L. 1988. Especies fúngicas encontradas en los cultivos de Canarias en el periodo 1974-84. Pages 43-50 in: III Congreso de la Sociedad Española de Fitopatología, Puerto de la Cruz, Canary Islands, Spain.

Gallo-Llobet, L., Hernández, J., and Jaizme, M. C. 1985. Enfermedades del aguacate presentes en Canarias, con especial referencia a Phytophthora cinnamomi Rands. (Podredumbre de raíz). Pages 7-19 in: II Congreso de la Sociedad Española de Fitopatología, Vitoria, Spain.

Gallo-Llobet, L., Miralles Ciscar, F., and Álvarez de la Peña, F. J. 1978. La podredumbre de las raíces del aguacate. Hoja divulgadora $\mathrm{N}^{\circ}$ 26-78 HDX. Ministerio de Agricultura, Madrid, Spain

Gerrettson-Cornell, L. 1994. A Compendium and Classification of the Species of the Genus Phytophthora de Bary by the Canons of the Traditional Taxonomy. Forestry Commission of New South Wales, Sydney, Australia.

Hardy, G. E., and Sivasithamparam, K. 1988. Phytophthora spp. associated with container-grown plants in nurseries in Western Australia. Plant Dis. 72: 435-437.

Hasegawa, M., Kishino, H., and Yano, T. 1985. Dating the human-ape split by a molecular clock of mitochondrial DNA. J. Mol. Evol. 22:160-174.

Hong, C. X., Gallegly, M. E., Browne, G. T., Bhat, R. G., Richardson, P. A., and Kong, P. 2009. The avocado subgroup of Phytophthora citricola constitutes a distinct species, Phytophthora mengei sp. nov. Mycologia 101:833-840.

Hüberli, D., Hardy, G. E. St. J., White, D., Williams, N., and Burgess, T. I. 2013. Fishing for Phytophthora from Western Australia's waterways: A distribution and diversity survey. Australas. Plant Pathol. 42:251-260.

Jeffers, S. N., and Martin, S. B. 1986. Comparison of two media selective for Phytophthora and Pythium species. Plant Dis. 70:1038-1043.

Jung, T., and Burgess, T. I. 2009. Re-evaluation of Phytophthora citricola isolates from multiple woody hosts in Europe and North America reveals a new species, Phytophthora plurivora sp. nov. Persoonia 22:95-110.

Jung, T., Orlikowski, L., Henricot, B., Abad-Campos, P., Aday, A. G., Aguín Casal, O., Bakonyi, J., Cacciola, S. O., Cech, T., Chavarriaga, D., Corcobado, T., Cravador, A., Decourcelle, T., Denton, G., Diamandis, S., Doğmuş-Lehtijärvi, H. T., Franceschini, A., Ginetti, B., Green, S., Glavendekić, M., Hantula, J., Hartmann, G., Herrero, M., Ivic, D., Horta Jung, M., Lilja, A., Keca, N., Kramarets, V., Lyubenova, A., Machado, H., Magnano di San Lio, G., Mansilla Vázquez, P. J., Marçais, B., Matsiakh, I., Milenkovic, I., Moricca, S., Nagy, Z. A., Nechwatal, J., Olsson, C., Oszako, T., Pane, A., Paplomatas, E. J., Pintos Varela, C., Prospero, S., Rial Martínez, C., Rigling, D., Robin, C., Rytkönen, A., Sánchez, M. E., Sanz Ros, A. V., Scanu, B., Schlenzig, A., Schumacher, J., Slavov, S., Solla, A., Sousa, E., Stenlid, J., Talgø, V., Tomic, Z., Tsopelas, P., Vannini, A., Vettraino, A. M., Wenneker, M., Woodward, S., and Peréz-Sierra, A. 2016. Widespread Phytophthora infestations in European nurseries put forest, seminatural and horticultural ecosystems at high risk of Phytophthora diseases. For. Pathol. 46:134-163.

Jung, T., Stukely, M. J. C., Hardy, G. E. St. J., White, D., Paap, T., Dunstan, W. A., and Burgess, T. I. 2011. Multiple new Phytophthora species from ITS clade 6 associated with natural ecosystems in Australia: Evolutionary and ecological implications. Persoonia 26:13-39.

Junker, C., Goff, P., Wagner, S., and Werres, S. 2016. Occurrence of Phytophthora in commercial nursery production. Plant Health Prog. 17:64-75.

Kimura, M. 1980. A simple method for estimating evolutionary rate of base substitutions through comparative studies of nucleotide sequences. J. Mol. Evol. 16:111-120.
Kong, P., Hong, C. X., and Richardson, P. A. 2003. Rapid detection of Phytophthora cinnamomi using PCR with primers derived from the $L p v$ putative storage protein genes. Plant Pathol. 52:681-693.

Lehtijärvi, A., Aday Kaya, A. G., Woodward, S., Jung, T., and Doğmus Lehtijärvi, H. T. 2017. Oomycota species associated with deciduous and coniferous seedlings in forest tree nurseries of western Turkey. For. Pathol. 47:e12363.

Leonberger, A. J., Speers, C., Ruhl, G., Creswell, T., and Beckerman, J. L. 2013 A survey of Phytophthora spp. in Midwest nurseries, greenhouses, and landscapes. Plant Dis. 97:635-640.

Lévesque, C. A., and De Cock, A. W. A. M. 2004. Molecular phylogeny and taxonomy of the genus Pythium. Mycol. Res. 108:1363-1383.

Loyd, A. L., Benson, D. M., and Ivors, K. L. 2014. Phytophthora populations in nursery irrigation water in relationship to pathogenicity and infection frequency of Rhododendron and Pieris. Plant Dis. 98:1213-1220.

Martin, F. N., Abad, Z. G., Balci, Y., and Ivors, K. 2012. Identification and detection of Phytophthora: Reviewing our progress, identifying our needs. Plant Dis. 96:1080-1103.

McLeod, A., Botha, W. J., Meitz, J. C., Spies, C. F. J., Tewoldemedhin, Y. T., and Mostert, L. 2009. Morphological and phylogenetic analyses of Pythium species in South Africa. Mycol. Res. 113:933-951.

Moralejo, E., Pérez-Sierra, A. M., Álvarez, L. A., Belbahri, L., Lefort, F., and Descals, E. 2009. Multiple alien Phytophthora taxa discovered on diseased ornamental plants in Spain. Plant Pathol. 58:100-110.

Mrázková, M., Černý, K., Tomšovský, M., Strnadová, V., Gregorová, B., Holub, V., Pánek, M., Havrdová, L., and Hejná, M. 2013. Occurrence of Phytophthora multivora and Phytophthora plurivora in the Czech Republic. Plant Prot. Sci. 49:155-164.

Nagle, A. M., Long, R. P., Madden, L. V., and Bonello, P. 2010. Association of Phytophthora cinnamomi with white oak decline in southern Ohio. Plant Dis. 94:1026-1034.

Nechwatal, J., Bakonyi, J., Cacciola, S. O., Cooke, D. E. L., Jung, T., Nagy, Z. A., Vannini, A., Vettraino, A. M., and Brasier, C. M. 2013. The morphology, behaviour and molecular phylogeny of Phytophthora taxon Salixsoil and its redesignation as Phytophthora lacustris sp. Plant Pathol. 62:355-369.

Oh, E., Gryzenhout, M., Wingfield, B. D., Wingfield, M. J., and Burgess, T. I 2013. Surveys of soil and water reveal a goldmine of Phytophthora diversity in South African natural ecosystems. IMA Fungus 4:123-131.

Parke, J. L., and Grünwald, N. J. 2012. A systems approach for management of pest and pathogens of nursery crops. Plant Dis. 96:1236-1244.

Parke, J. L., Knaus, B. J., Fieland, V. J., Lewis, C., and Grunwald, N. J. 2014 Phytophthora community structure analyses in Oregon nurseries inform systems approaches to disease management. Phytopathology 104:1052-1062.

Pegg, K. G., Coates, L. M., Korsten, L., and Harding, R. M. 2002. Foliar, fruit and soilborne diseases. Pages 299-338 in: The Avocado: Botany, Production and Uses. A. W. Whiley, B. Schaffer, and B. N. Wolstenholme, eds. CAB International, Wallingford, U.K.

Pérez-Sierra, A., León, M., Álvarez, L. A., Alaniz, S., Berbegal, M., GarcíaJiménez, J., and Abad-Campos, P. 2010. Outbreak of a new Phytophthora sp. associated with severe decline of almond trees in Eastern Spain. Plant Dis. 94:534-541.

Pérez-Sierra, A., Mora-Sala, B., León, M., García-Jiménez, J., and Abad-Campos, P. 2012. Enfermedades causadas por Phytophthora en viveros de plantas ornamentales. Bol. Sanid. Veg., Plagas 38:143-156.

Prigigallo, M. I., Mosca, S., Cacciola, S. O., Cooke, D. E. L., and Schena, L. 2015 Molecular analysis of Phytophthora diversity in nursery-grown ornamental and fruit plants. Plant Pathol. 64:1308-1319.

Prospero, S., Vercauteren, A., Heungens, K., Belbahri, L., and Rigling, D. 2013. Phytophthora diversity and the population structure of Phytophthora ramorum in Swiss ornamental nurseries. Plant Pathol. 62:1063-1071.

Reeser, P. W., Sutton, W., Hansen, E. M., Remigi, P., and Adams, G. C. 2011 Phytophthora species in forest streams in Oregon and Alaska. Mycologia 103:22-35.

Robideau, G. P., De Cock, A. W. A. M., Coffey, M. D., Voglmayr, H., Brouwer, H., Bala, K., Chitty, D. W., Désaulniers, N., Eggertson, Q. A., Gachon, C. M M., Hu, C. H., Küpper, F. C., Rintoul, T. L., Sarhan, E., Verstappen, E. C. P., Zhang, Y., Bonants, P. J. M., Ristaino, J. B., and Lévesque, C. A. 2011. DNA barcoding of oomycetes with cytochrome $c$ oxidase subunit I and internal transcribed spacer. Mol. Ecol. Resour. 11:1002-1011.

Rodríguez-Padrón, C., Siverio, F., Pérez-Sierra, A., and Rodríguez, A. 2018 Several Phytophthora species and Pythium vexans complex as new threats to avocado orchards in the Canary Islands. Phytopathol. Mediterr. 57:89-106.

Saitou, N., and Nei, M. 1987. The neighbor-joining method: A new method for reconstruction phylogenetic trees. Mol. Biol. Evol. 4:406-425.

Scanu, B., Hunter, G. C., Linaldeddu, B. T., Franceschini, A., Maddau, L., Jung, T., and Denman, S. 2014. A taxonomic re-evaluation reveals that Phytophthora cinnamomi and P. cinnamomi var. parvispora are separate species. For. Pathol. 44:1-20.

Schwingle, B. W., Smith, J. A., and Blanchette, R. A. 2007. Phytophthora species associated with diseased woody ornamentals in Minnesota nurseries. Plant Dis. 91:97-102.

Scott, P. M., Burgess, T. I., Barber, P. A., Shearer, B. L., Stukely, M. J. C., Hardy, G. E. St. J., and Jung, T. 2009. Phytophthora multivora sp. nov., a new species 
recovered from declining Eucalyptus, Banksia, Agonis and other plant species in Western Australia. Persoonia 22:1-13.

Sims, L., Tjosvold, S., Chambers, D., and Garbelotto, M. 2019. Control of Phytophthora species in plant stock for habitat restoration through best management practices. Plant Pathol. 68:196-204.

Spies, C. F. J., Mazzola, M., Botha, W. J., Van Der Rijst, M., Mostert, L., and McLeod, A. 2011a. Oogonial biometry and phylogenetic analyses of the Pythium vexans species group from woody agricultural hosts in South Africa reveal distinct groups within this taxon. Fungal Biol. 115:157-168.

Spies, C. F. J., Mazzola, M., and McLeod, A. 2011b. Characterisation and detection of Pythium and Phytophthora species associated with grapevines in South Africa. Eur. J. Plant Pathol. 131:103-119.

Stamler, R. A., Sanogo, S., Goldberg, N. P., and Randall, J. J. 2016. Phytophthora species in rivers and streams of the southwestern United States. Appl. Environ. Microbiol. 82:4696-4704.

Tamura, K., Stecher, G., Peterson, D., Filipski, A., and Kumar, S. 2013. MEGA6: Molecular Evolutionary Genetics Analysis version 6.0. Mol. Biol. Evol. 30:2725-2729.

Thompson, J. D., Higgins, D. G., and Gibson, T. J. 1994. CLUSTAL W: Improving the sensitivity of progressive multiple sequence alignment through sequence weighting, position specific gap penalties and weight matrix choice. Nucleic Acids Res. 22:4673-4680.

Uzuhashi, S., Tojo, M., and Kakishima, M. 2010. Phylogeny of the genus Pythium and description of new genera. Mycoscience 51:337-365.

Waterhouse, G. M., Newhook, F. J., and Stamps, D. J. 1983. Present criteria for classification of Phytophthora. Pages 139-147 in: Phytophthora: Its Biology, Taxonomy, Ecology, and Pathology. D. C. Erwin, S. Bartnicki-Garcia, and P. Tsao, eds. American Phytopathological Society Press, St. Paul, MN

White, T. J., Bruns, T., Lee, S., and Taylor, J. 1990. Amplification and direct sequencing of fungal ribosomal RNA genes for phylogenetics. Pages 315-322 in: PCR Protocols: A Guide to Methods and Applications. M. A Innis, D. H. Gelfand, J. J. Sninsky, and T. J. White, eds. Academic Press, San Diego, CA.

Zappia, R. E., Hüberli, D., Hardy, G. E. St. J., and Bayliss, K. L. 2014. Fungi and oomycetes in open irrigation systems: Knowledge gaps and biosecurity implications. Plant Pathol. 63:961-972.

Zentmyer, G. A. 1980. Phytophthora cinnamomi and the Diseases It Causes. American Phytopathological Society, St. Paul, MN.

Zentmyer, G. A., Thorn, W. A., Paulus, O. A., and Burns, R. M. 1958. Hot water treatment of avocado seed. Calif. Avocado Soc. Yearb. 42:108-110. 